\title{
DAMPAK MENU SEPINGGAN TERHADAP KONSUMSI DAN TINGKAT KECUKUPAN ENERGI SERTA ZAT GIZI LAIN PADA SISWA SD
}

\author{
(The effect of One-dish Meal on Dietary Intake and Adequacy Level of Energy, \\ Other Nutrients of Elementary School Children)
}

\author{
Tiurma Sinaga ${ }^{1 *}$, Clara M Kusharto ${ }^{1}$, Budi Setiawan ${ }^{1}$, dan Ahmad Sulaeman ${ }^{1}$ \\ ${ }^{1}$ Departemen Gizi Masyarakat, Fakultas Ekologi Manusia (FEMA), Institut Pertanian Bogor, \\ Jl. Raya Darmaga, 16680
}

\begin{abstract}
The objective of this study was to analyze the effect of one dish meal breakfast on dietary intake and adequacy level of energy and other nutrients of elementary school children. The study used pre-experimental one-group pretest-posttest design and was conducted from March to May 2011 at Kebon Kopi 2 Public Elementary School in Bogor City. The total number of sixty two elementary students were fully participated in this study, most of them were girls aged 11 years old. The Ethical Approval for this study was obtained from Komisi Etik Badan Penelitian dan Pengembangan Kesehatan No. KE.01.05/EC/301/2011. The study showed that there was significant difference before and after giving one dish meal breakfast as school feeding among the elementary school children $(p<0.05)$. It's positively affected to increase the level of dietary intake of energy by $27.0 \%$, protein by $31.3 \%$, vitamin $A$ by $42.3 \%$, and iron by $30.0 \%$ of the elementary school children. One dish meal breakfast significantly affected the adequacy of energy, protein, vitamin $A$ and Fe of the elementary school children $(p<0.05)$.
\end{abstract}

Key words: one dish meal, breakfast school, dietary intakes, nutrient adequacy, elementary school children

\begin{abstract}
ABSTRAK
Tujuan dari penelitian ini adalah untuk menganalisis pengaruh pemberian sarapan menu sepinggan terhadap konsumsi dan tingkat kecukupan energi dan zat gizi lainnya pada siswa SD. Penelitian menggunakan pra eksperimental dengan desain one-group pretest-posttest yang dilakukan pada bulan Maret sampai Mei $2011 \mathrm{di}$ Sekolah Dasar Negeri (SDN) Kebon Kopi 2 Kota Bogor. Jumlah siswa yang berpartisipasi dalam penelitian ini sebanyak 62 orang dan sebagian besar dari siswa adalah anak perempuan berusia 11 tahun. Penelitian ini telah mendapat persetujuan Etik (Ethical Approval) dari Komisi Etik Badan Penelitian dan Pengembangan Kesehatan Nomor KE.01.05/EC/301/2011. Hasil penelitian menunjukkan bahwa pemberian sarapan menu sepinggan di sekolah secara nyata berpengaruh $(p<0.05)$ terhadap peningkatan asupan energi dan zat gizi lainnya pada siswa. Peningkatan asupan terhadap energi sebesar $27.0 \%$, protein $31.3 \%$, vitamin A $42.3 \%$, dan $\mathrm{Fe} 30.0 \%$ pada siswa SDN Kebon Kopi 2 kota Bogor. Hasil penelitian juga menunjukkan bahwa pemberian sarapan menu sepinggan secara nyata berpengaruh $(p<0.05)$ terhadap tingkat kecukupan energi, protein, vitamin A dan Fe.
\end{abstract}

Kata kunci: menu sepinggan, makan pagi di sekolah, asupan makanan, kecukupan gizi, siswa SD

"Korespondensi: Departemen Gizi Masyarakat, Fakultas Ekologi Manusia (FEMA), Institut Pertanian Bogor, Jl. Raya Darmaga, 16680. Tel: 0251-86251258; Fax: 0251-8622276; Email: s_tiurmav@hotmail.com 


\section{PENDAHULUAN}

Pembangunan Sumber Daya Manusia (SDM) merupakan kunci utama dari keberhasilan pembangunan nasional jangka panjang. Pembangunan Sumber Daya Manusia diarahkan untuk membangun manusia berkualitas baik dari aspek fisik maupun rohani secara seimbang. Kualitas SDM Indonesia relatif rendah dibandingkan dengan negara-negara di Asia Tenggara lainnya.

Permasalahan yang dihadapi dalam SDM di bidang pendidikan adalah angka putus sekolah yang masih dialami oleh 3.0\% siswa. Meskipun belum ada penelitian khusus, diduga penyebab putus sekolah adalah rendahnya keadaan kesehatan dan gizi anakanak serta kemiskinan orang tua mereka, sehingga tenaga mereka lebih diperlukan untuk membantu mencari nafkah (KEMENDAGRI 2010).

Survei tahun 1990 menunjukkan bahwa 70\% anak-anak di desa miskin mengonsumsi makanan kurang dari 70\% kebutuhan energi sehari mereka; 40\% anak-anak anemia dan kira-kira $50-80 \%$ anakanak terkena infeksi cacing (Studdert \& Soekirman 1998). Laporan lain mengungkapkan bahwa anak sekolah di Indonesia yang menderita gizi kurang kronik sedang (stunting) hanya berkurang 3.7\% yaitu dari 39.8\% tahun 1994 menjadi 36.1\% pada tahun 1999. Hal ini mengindikasikan bahwa hanya sedikit yang dapat dilakukan oleh Pemerintah untuk menyelesaikan masalah kekurangan gizi anak sekolah tersebut. Oleh karena itu, harus dilakukan usaha pencegahan secara menyeluruh (komprehensif) yang dapat dilaksanakan sebagai upaya pemecahan masalah tersebut (Judhiastuty 2005).

Banyak intervensi yang telah dilakukan pada beberapa tahun terakhir ini, yang bertujuan meningkatkan kemampuan siswa, terutama bagi me- reka yang kurang gizi. Di antara intervensi tersebut, program pemberian makan pagi (sarapan) di sekolah sering dianggap sebagai intervensi yang efektif untuk meningkatkan efisiensi pendidikan di sekolah-sekolah miskin di negara berkembang (Cueto 2008). Program sarapan di sekolah ditargetkan untuk me- ngurangi kelaparan dan meningkatkan status gizi anak, terutama mereka yang kurang gizi (Powell et al. 1998). Anak sekolah di negara sedang berkembang umumnya menderita kelaparan jangka pendek, kekurangan energi protein, dan kekurangan yodium, vitamin A, dan besi. Anak usia sekolah yang mengalami kekurangan gizi tertentu dalam makanan mereka, terutama besi dan iodium, atau yang menderita kekurangan energi-protein, kelaparan, dan atau infeksi parasit atau penyakit lain, tidak memiliki kapasitas yang sama untuk belajar seperti anak yang sehat dan gizinya baik (Cueto 2008).

Selama ini, program Pemberian Makanan Tambahan Anak Sekolah (PMT-AS) di Indonesia mengandalkan jenis makanan jajanan setempat. Keluhan di lapangan menunjukkan adanya rasa bosan dan ukuran porsi yang tidak dihabiskan anak sehingga jumlah zat gizi tidak sebanyak yang diharapkan (Soetrisno 2005). PMT-AS hanya menyediakan makanan berupa kudapan, sedangkan penyelenggaraan sarapan di sekolah dapat menyediakan makanan lengkap berupa menu sepinggan (one dish meal), sehingga manfaatnya diharapkan akan lebih baik. Makanan lengkap ini dapat memenuhi $20.0 \%$ dari kecukupan anak sekolah dalam sehari, sedangkan PMT-AS hanya memenuhi $15.0 \%$.

Program sarapan di sekolah (breakfast school) dapat dilaksanakan dengan mempergunakan dapur sekolah atau dapur diluar gedung sekolah. Hal ini tergantung dari fasilitas yang tersedia di sekolah tersebut. Tenaga pelaksana yang menyelenggarakan sarapan di sekolah dapat dilakukan oleh tenaga yang dibayar oleh sekolah atau dibayar oleh orang tua murid melalui komite sekolah.

Hasil penelitian pendahuluan menunjukkan bahwa status gizi berdasarkan indikator BB/U siswa kelas 5 dan 6 SDN Kebon Kopi 2 kota Bogor adalah sebesar $38.7 \%$ termasuk kategori gizi kurang dan $75.8 \%$ orang tua siswa termasuk dalam kategori miskin.

Tujuan penelitian ini adalah mengetahui dampak pemberian sarapan menu sepinggan terhadap konsumsi dan tingkat kecukupan energi, protein, vitamin A dan besi (Fe) pada siswa SDN Kebon Kopi 2 Kota Bogor.

\section{METODE}

\section{Desain, Tempat, dan Waktu Penelitian}

Penelitian ini menggunakan desain one-group pretest-posttest. Penelitian dilaksanakan di SDN Kebon Kopi 2 kota Bogor. Pemilihan SDN Kebon Kopi 2 dilakukan secara purposive, dengan kriteria SDN yang pernah menerima PMT-AS (IDT/Inpres Daerah Tertinggal), SDN yang mempunyai 1 kelas dari masing-masing tingkatan kelas, SDN yang berada di wilayah kerja Puskesmas Merdeka yang mempunyai Tenaga Pelaksana Gizi (TPG) dan mudah akses transportasi. Penelitian ini dilaksanakan pada bulan Maret sampai Mei 2011.

\section{Populasi dan Sampel}

Populasi studi adalah semua murid di SDN 
Kebon Kopi 2 kota Bogor. Cara pengambilan contoh dengan cara purposive sampling yaitu siswa kelas 5 dan kelas 6 , dengan menggunakan kriteria inklusi yaitu siswa dapat memahami dan mengisi kuesioner dengan baik, jumlah seluruh siswa kelas 5 dan kelas 6 telah memenuhi syarat untuk sebuah penyelenggaraan makanan institusi anak sekolah, yaitu $>50$ porsi untuk satu kali pelaksanaan, dan mau berpartisipasi dalam penelitian dengan menandatangani informed consent. Jumlah contoh dalam penelitian ini sebanyak 62 siswa, yang terdiri dari 33 kelas 5 dan 29 kelas 6. Penelitian ini telah mendapatkan persetujuan Etik (Ethical Approval) dari Komisi Etik Badan Penelitian dan Pengembangan Kesehatan Nomor : KE.01.05/EC/301/2011.

\section{Jenis dan Cara Pengambilan Data}

Data karakteristik contoh (tanggal lahir, berat badan, uang jajan per hari) dan karakteristik keluarga (pendidikan, pekerjaan, dan pendapatan orang tua) dikumpulkan menggunakan kuesioner yang diisi oleh contoh setelah diberi penjelasan dari peneliti. Data berat badan dikumpulkan menggunakan timbangan digital merk first choice (ketelitian $0.1 \mathrm{~kg}$ ). Salah satu cara mengukur data konsumsi pangan anak usia 6-17 tahun adalah dengan food record (Boushey et al. 2009). Data konsumsi pangan contoh sebelum pemberian sarapan menu sepinggan dikumpulkan dengan metode food record selama 6 hari. Data konsumsi pangan sarapan selama penelitian dikumpulkan dengan metode self-reported consumption yaitu mengukur berapa banyak makanan yang dapat dihabiskan, dengan 6 skala pengukuran: dimakan habis, dimakan 3/4 bagian, dimakan $1 / 2$ bagian, dimakan $1 / 4$ bagian, hanya dicicipi, dan tidak dimakan (Comstock 1981).

\section{Pengolahan dan Analisis Data}

Analisis data dilakukan secara deskriptif dan inferensial. Data jumlah pangan yang dikonsumsi dikonversikan ke dalam energi dan zat gizi yang meliputi: protein, vitamin A, dan Fe dengan menggunakan DKBM. Pengukuran tingkat kecukupan gizi (\%AKG) dilakukan dengan membandingkan kandungan zat gizi semua makanan yang dimakan oleh siswa selam 24 jam dengan AKG 2004 dalam persen. Tingkat kecukupan vitamin A dan Fe digolongkan menjadi cukup dan kurang. Untuk mengetahui perbedaan konsumsi dan tingkat kecukupan energi, protein, vitamin A, dan Fe siswa sebelum dan sesudah pemberian sarapan menu sepinggan dilakukan uji beda $t$.

\section{HASIL DAN PEMBAHASAN}

\section{Karakteristik Contoh}

Sebagian besar $(56.5 \%)$ atau 35 contoh berjenis kelamin perempuan. Tabel 1 menggambarkan bahwa contoh sebesar $44.5 \%$ adalah laki-laki dan 42.9\% adalah perempuan yang berada pada usia 11 tahun. Anak usia 6 sampai 12 tahun termasuk dalam fase akhir masa anak-anak (late childhood) sampai tiba saatnya anak menjadi matang secara seksual yaitu pada usia 13 tahun bagi anak perempuan dan 14 tahun bagi anak laki-laki. Golongan usia anak sekolah, yaitu dimana anak belum mencapai dewasa tetapi sedang dalam tahap pertumbuhan (golden-age). Oleh karena itu, pada usia ini perlu diperhatikan asupan makanan yang adekuat jumlah dan kualitasnya.

Besar uang jajan merupakan sejumlah uang yang diterima siswa dalam sehari untuk membeli jajanan. Uang jajan anak sekolah menjadi suatu kebiasaan, baik yang berasal dari keluarga dengan pendapatan yang rendah maupun tinggi. Sebagian besar (67.7\%) contoh memiliki uang jajan $\leq \mathrm{Rp} 3000$. Jumlah uang jajan ini mengindikasikan bahwa sebagian besar siswa tersebut berasal dari keluarga miskin, karena besar kecilnya uang jajan dipengaruhi oleh besarnya pendapatan keluarga.

Tabel 1. Cara Penentuan Skor Peubah dalam Penelitian

\begin{tabular}{ccccccc}
\hline \multirow{2}{*}{ Umur } & \multicolumn{2}{c}{ Laki-laki } & \multicolumn{2}{c}{ Perempuan } & \multicolumn{2}{c}{ Total } \\
\cline { 2 - 7 } & $\mathrm{n}$ & $\%$ & $\mathrm{n}$ & $\%$ & $\mathrm{n}$ & $\%$ \\
\hline 9 & 0 & 0 & 1 & 2.8 & 1 & 1.6 \\
10 & 7 & 25.9 & 9 & 25.7 & 16 & 25.8 \\
11 & 12 & 44.5 & 15 & 42.9 & 27 & 43.6 \\
12 & 7 & 25.9 & 8 & 22.9 & 15 & 24.2 \\
13 & 1 & 3.7 & 2 & 5.7 & 3 & 4.8 \\
Total & 27 & 100.0 & 35 & 100.0 & 62 & 100.0 \\
\hline
\end{tabular}




\section{Karakteristik Orang Tua Contoh \\ Pendidikan}

Pendidikan seseorang akan mempengaruhi sikap dan perilaku makan dalam kehidupan seharihari. Pada Tabel 2, terlihat bahwa sebagian besar (43.1\%) pendidikan ayah contoh adalah tamat SMA, sedangkan pendidikan ibu contoh (36.7\%) hanya tamat SD. Dari Tabel 2 dapat diketahui juga bahwa tingkat pendidikan ayah contoh lebih tinggi dibandingkan tingkat pendidikan ibu contoh. Tingkat pendidikan ibu mempengaruhi derajat kesehatan keluarga. Ibu yang memiliki pendidikan tinggi cenderung memiliki pengetahuan gizi, kesehatan dan pengasuhan anak yang baik. Pendidikan ibu merupakan salah satu faktor penentu mortalitas anak, karena tingkat pendidikan ibu berpengaruh terhadap pemahaman dalam perawatan kesehatan, higiene, dan kesadaran dalam menjaga kesehatan anak dan keluarga.

\section{Pekerjaan}

Pekerjaan atau mata pencaharian berperan penting dalam kehidupan sosial ekonomi keluarga. Anak yang tumbuh dalam keluarga miskin paling rawan terhadap kekurangan gizi diantara anggota keluarga lainnya. Pekerjaan ayah contoh sebagian besar (27.6\%) adalah buruh pabrik, sebesar 25.9\% bekerja sebagai buruh bangunan atau kuli, bahkan ada yang tidak bekerja secara rutin sebanyak 5.2\%. Pekerjaan orang tua terutama ibu yang bekerja akan mempengaruhi kebiasaan makan dalam keluarga. Hal ini disebabkan karena umumnya ibu terlibat langsung dalam perencanaan menu dan penyediaan makanan keluarga. Ibu yang bekerja tidak lagi memiliki waktu untuk mempersiapkan makanan bagi keluarganya. Tabel 2 menunjukkan bahwa sebagian besar (83.3\%) adalah ibu rumah tangga, tetapi terdapat juga ibu yang bekerja sebagai buruh (tukang cuci). Hal inilah yang diduga sebagai penyebab kondisi ekonomi contoh sebagian besar termasuk miskin.

\section{Pendapatan}

Sebagian besar (75.8\%) contoh memiliki pendapatan keluarga yang termasuk dalam kategori miskin (< Rp 278 530) dan sisanya (24.2\%) termasuk kategori tidak miskin ( $\geq$ Rp 278 530). Hal ini dikare-

Tabel 2. Distribusi Orang Tua Contoh berdasarkan Tingkat Pendidikan dan Pekerjaan

\begin{tabular}{|c|c|c|c|c|}
\hline \multirow{2}{*}{ Karakteristik } & \multicolumn{2}{|c|}{ Ayah } & \multicolumn{2}{|c|}{ Ibu } \\
\hline & $\mathrm{n}$ & $\%$ & $\mathrm{n}$ & $\%$ \\
\hline \multicolumn{5}{|l|}{ Pendidikan } \\
\hline Tidak sekolah & 1 & 1.7 & 0 & 0.0 \\
\hline SD & 16 & 27.6 & 22 & 36.7 \\
\hline SMP & 13 & 22.4 & 20 & 33.3 \\
\hline SMA & 25 & 43.1 & 18 & 30.0 \\
\hline Perguruan tinggi & 3 & 5.2 & 0 & 0.0 \\
\hline Total & 58 & 100.0 & 60 & 100.0 \\
\hline \multicolumn{5}{|l|}{ Pekerjaan } \\
\hline Tidak bekerja & 3 & 5.2 & 50 & 83.3 \\
\hline Buruh bangunan atau kuli & 15 & 25.9 & 1 & 1.7 \\
\hline Pedagang keliling, asongan & 12 & 20.7 & 6 & 10.0 \\
\hline PNS & 2 & 3.4 & 0 & 0.0 \\
\hline Buruh pabrik & 16 & 27.6 & 3 & 5.0 \\
\hline Jasa (supir angkot, ojeg) & 10 & 17.2 & 0 & 0.0 \\
\hline Total & 58 & 100.0 & 60 & 100.0 \\
\hline
\end{tabular}

Tabel 3. Kandungan Energi, Protein, Vitamin A dan Fe Sarapan Menu Sepinggan dan Kontribusinya (\%) terhadap AKG Siswa Kelas 5 dan Kelas 6 SD

\begin{tabular}{|c|c|c|c|c|c|c|c|c|c|}
\hline \multirow{3}{*}{ Jenis Menu Sepinggan } & \multicolumn{2}{|c|}{ Energi } & \multicolumn{2}{|c|}{ Protein } & \multicolumn{2}{|c|}{ Vit. A } & \multicolumn{3}{|c|}{$\mathrm{Fe}$} \\
\hline & \multirow{2}{*}{ kkal } & \multirow{2}{*}{$\%$ AKG } & \multirow{2}{*}{ g } & \multirow{2}{*}{$\%$ AKG } & \multirow{2}{*}{ ug RE } & \multirow{2}{*}{$\%$ AKG } & \multirow{2}{*}{$\mathrm{mg}$} & \multicolumn{2}{|c|}{$\%$ AKG } \\
\hline & & & & & & & & Laki-laki & Perempuan \\
\hline Mie goreng & 419 & 20.8 & 9.6 & 19.2 & 280.3 & 46.7 & 3.4 & 26.2 & 17.0 \\
\hline Nasi uduk kuning & 453 & 22.1 & 8.7 & 17.4 & 69.5 & 11.6 & 1.3 & 10.0 & 6.5 \\
\hline Lontong sayur & 404 & 19.7 & 7.9 & 15.8 & 228.7 & 38.1 & 1.2 & 9.2 & 6.0 \\
\hline Bubur ayam & 430 & 21.0 & 9.4 & 18.8 & 200.1 & 33.3 & 1.0 & 7.7 & 5.0 \\
\hline Gado-gado lontong & 475 & 23.2 & 16.0 & 32.0 & 233.0 & 38.3 & 3.8 & 29.2 & 19.0 \\
\hline Nasi goreng & 432 & 21.1 & 8.4 & 16.8 & 80.8 & 13.6 & 1.3 & 10.0 & 6.5 \\
\hline Rata-rata & 436 & 21.3 & 10.0 & 20.0 & 136.6 & 30.35 & 1.97 & 15.4 & 10.0 \\
\hline
\end{tabular}


nakan masih banyaknya jenis pekerjaan orang tua sebagai buruh serta terdapat beberapa orang tua yang belum memiliki pekerjaan tetap. Selain itu, sebagian besar lbu contoh hanya sebagai ibu rumah tangga, sehingga besarnya pendapatan keluarga hanya diperoleh dari penghasilan pekerjaan ayah saja.

Kandungan dan Kontribusi Energi, Protein, Vitamin A dan Fe Menu Sepinggan terhadap AKG siswa kelas 5 dan kelas 6 SD

Menu sepinggan yang disajikan kepada contoh adalah menu yang disukai oleh siswa. Menu yang disukai oleh siswa diperoleh dari hasil kuesioner melalui food preference untuk anak (berupa smile face) yang dilakukan sebelum pemberian menu sepinggan. Tabel 3 adalah siklus menu 6 hari (Senin s/d Sabtu) yang dipergunakan selama penelitian. Tujuan penggunaan siklus menu adalah untuk menghindari kebosanan siswa terhadap menu yang disajikan selama 2 minggu berturut-turut. Pada Tabel 3 diketahui bahwa rata-rata nilai sarapan menu sepinggan telah memenuhi syarat untuk energi sebesar $21.3 \%$, protein sebesar 20.0\%, dan vitamin A sebesar 30.35\%, tetapi untuk sumber Fe belum memenuhi syarat karena hanya berkontribusi 15.4\% (laki-laki) dan 10\% (perempuan). Bahan pangan yang berasal dari protein hewani, seperti daging, hati, ayam, ikan adalah sumber Fe. Sumber protein hewani ini dapat menghabiskan $1 / 2$ bahkan $2 / 3$ dari dana penyelenggaraan makanan anak sekolah, lalu diikuti bahan pangan sumber protein nabati. Pada proses perencanaan menu penyelenggaraan makanan anak sekolah, pertama-tama yang harus diperhatikan adalah kecukupan gizi siswa, tetapi juga harus mempertimbangkan dana yang tersedia (Sinaga 2007). Dengan dana yang sesuai dengan kondisi siswa (67.7\% uang jajan contoh $\leq$ Rp 3 000), maka dibuatlah menu sepinggan yang seimbang, dan biaya rata-rata Rp 3000 .

\section{Konsumsi dan Tingkat Kecukupan Energi}

Energi merupakan salah satu hasil metabolisme karbohidrat, protein, dan lemak, yang berfungsi sebagai zat tenaga untuk metabolisme, pertumbuhan, pengatur suhu dan kegiatan fisik. Kelebihan energi disimpan sebagai cadangan energi dalam bentuk glikogen sebagai cadangan energi jangka pendek dan dalam bentuk lemak sebagai cadangan jangka panjang. Rata-rata konsumsi energi contoh sebelum pemberian sarapan adalah 1146 kkal, dan sesudah pemberian sarapan menu sepinggan menjadi 1577 kkal. Peningkatan asupan energi tersebut sebesar $27.0 \%$. Berdasarkan hasil uji statistik menggunakan uji beda $t$, terdapat perbedaan yang signifikan antara rata-rata konsumsi energi sebelum dan sesudah pemberian sarapan $(p<0.05)$. Hasil penelitian ini mendukung studi Jacoby dan Pollitt (1996), yang menyatakan bahwa program sarapan sekolah di Peru secara signifikan meningkatkan asupan energi sebesar 15.2\%. Dan juga hasil penelitian Kustiyah dkk. (2006), yang menunjukkan bahwa intervensi makanan kudapan (buras) yang mengandung energi 82.3 $\mathrm{Kkal}$ dan protein 5 gram dapat meningkatkan konsumsi energi secara nyata.

Rata-rata tingkat kecukupan energi (TKE) contoh sebelum pemberian sarapan adalah $60.21 \%$ dan sesudah pemberian menjadi $87.23 \%$. Sebagian besar (75.8\%) tingkat kecukupan energi per hari contoh sebelum pemberian menu sepinggan masih berada di bawah AKE, dan masuk dalam kategori defisit berat. Data ini sesuai dengan hasil Riskesdas 2010 yang menyatakan bahwa rata-rata kecukupan energi secara nasional pada anak usia 7-12 tahun adalah 71.6-89.1\% (Salimar 2011). Widyakarya Nasional Pangan dan Gizi (WNPG) 2004 menetapkan kecukupan energi anak usia 9 tahun sebesar 1800 kkal, anak usia 10-12 tahun sebesar 2050 kkal, dan kecukupan energi anak usia 13-15 tahun adalah sebesar 2400 kkal (laki-laki) dan 2350 kkal (perempuan).

Tabel 4. Distribusi Rata-rata Tingkat Kecukupan Energi dan Protein Contoh Sebelum dan Sesudah Pemberian Sarapan Menu Sepinggan

\begin{tabular}{|c|c|c|c|c|c|c|c|c|}
\hline \multirow{3}{*}{ Klasifikasi } & \multicolumn{4}{|c|}{ Sebelum } & \multicolumn{4}{|c|}{ Sesudah } \\
\hline & \multicolumn{2}{|c|}{ Energi } & \multicolumn{2}{|c|}{ Protein } & \multicolumn{2}{|c|}{ Energi } & \multicolumn{2}{|c|}{ Protein } \\
\hline & $\mathrm{n}$ & $\%$ & $\mathrm{n}$ & $\%$ & $\mathrm{n}$ & $\%$ & $\mathrm{n}$ & $\%$ \\
\hline Di atas angka kecukupan ( $\geq 120 \% A K G)$ & 0 & 0.0 & 1 & 1.6 & 7 & 11.3 & 9 & 14.5 \\
\hline Normal (90-119\%AKG) & 6 & 9.7 & 4 & 6.5 & 15 & 24.2 & 14 & 22.6 \\
\hline Defisit ringan (80-89\%AKG) & 4 & 6.5 & 5 & 8.1 & 9 & 14.5 & 9 & 14.5 \\
\hline Defisit sedang (70-79\%AKG) & 5 & 8.1 & 6 & 9.7 & 7 & 11.3 & 8 & 12.9 \\
\hline Defisit berat (<70\%AKG) & 47 & 75.8 & 46 & 74.2 & 24 & 38.7 & 22 & 35.5 \\
\hline Total & 62 & 100.0 & 62 & 100.0 & 62 & 100.0 & 62 & 100.0 \\
\hline
\end{tabular}


Pemberian sarapan menu sepinggan berdampak positif terhadap tingkat kecukupan contoh, hal ini dapat dilihat dari menurunnya jumlah contoh yang termasuk dalam kategori defisit berat (dari $75.8 \%$ turun menjadi $38.7 \%$ ), dan yang termasuk kategori normal meningkat dari $9.7 \%$ menjadi $24.2 \%$ (Tabel 4). Berdasarkan hasil uji statistik menggunakan uji beda $t$, terdapat perbedaan yang signifikan antara rata-rata tingkat kecukupan energi sebelum dan sesudah pemberian sarapan $(p<0.05)$.

\section{Konsumsi dan Tingkat Kecukupan Protein}

Rata-rata konsumsi protein contoh sebelum pemberian sarapan adalah 27.8 gram, dan sesudah pemberian sarapan menu sepinggan menjadi 39.9 gram. Berdasarkan hasil uji statistik menggunakan uji beda $t$, terdapat perbedaan yang signifikan antara rata-rata konsumsi protein contoh sebelum dan sesudah pemberian menu sepinggan $(p<0.05)$. Peningkatan asupan protein tersebut sebesar 31.3\%. Hasil ini mendukung studi Jacoby dan Pollitt (1996), yang menyatakan bahwa program sarapan sekolah di Peru secara signifikan meningkatkan asupan protein sebesar $16.1 \%$. Dan hasil penelitian Kustiyah dkk. (2006), juga menunjukkan bahwa intervensi makanan kudapan (buras) yang mengandung energi 82.3 kkal dan protein 5 gram dapat meningkatkan konsumsi protein secara nyata. Angka kecukupan protein anak usia 9 tahun sebesar 45 gram, anak usia 10-12 tahun sebesar 50 gram, dan anak usia 1315 tahun sebesar 60 gram (laki-laki) dan 57 gram (perempuan) (WNPG 2004).

Rata-rata tingkat kecukupan protein (TKP) contoh sebelum pemberian sarapan adalah 59.64\% dan sesudah pemberian menjadi $90.90 \%$. Sebagian besar (74.2\%) tingkat kecukupan protein per hari contoh sebelum pemberian menu sepinggan masih berada di bawah AKP, dan masuk dalam kategori defisit berat. Data penelitian ini lebih kecil dari data Riskesdas 2010 yang menyatakan bahwa ratarata kecukupan protein secara nasional pada anak umur 7-12 tahun berkisar antara $85.1 \%-137.4 \%$, dan persentase anak umur 7-12 tahun yang mengonsumsi protein dibawah kebutuhan minimal adalah $30.6 \%$. Hasil penelitian ini mengindikasikan bahwa kecukupan protein contoh masih berada di bawah angka rata-rata nasional. Hal ini diduga sebagai pengaruh kondisi ekonomi contoh yang sebagian besar termasuk miskin sehingga berpengaruh terhadap kualitas dan kuantitas pangan yang dikonsumsi. Kekurangan protein banyak terdapat pada masyarakat sosial ekonomi rendah dan sering ditemukan secara bersamaan dengan kekurangan energi yang menyebabkan
Kekurangan Energi Protein/KEP (Kikafunda 2006). Angka kecukupan protein anak usia 9 tahun sebesar 45 gram, anak usia 10-12 tahun sebesar 50 gram, dan anak usia 13-15 tahun sebesar 60 gram (lakilaki) dan 57 gram (perempuan) (WNPG 2004).

Pemberian sarapan menu sepinggan berdampak positif terhadap tingkat kecukupan contoh. Hal ini dapat dilihat dari menurunnya jumlah contoh yang termasuk dalam kategori defisit berat (dari $74.2 \%$ turun menjadi $35.5 \%$ ), dan yang termasuk kategori normal meningkat dari $6.5 \%$ menjadi $22.6 \%$. Berdasarkan hasil uji statistik menggunakan $u j i$ beda $t$, terdapat perbedaan yang signifikan antara rata-rata tingkat kecukupan protein sebelum dan sesudah pemberian sarapan menu sepinggan $(p<0.05)$.

\section{Konsumsi dan Tingkat Kecukupan Vitamin A}

Vitamin A esensial untuk pemeliharaan kesehatan dan kelangsungan hidup. Kekurangan vitamin A dapat meningkatkan resiko anak terhadap penyakit infeksi seperti penyakit saluran pernapasan dan diare, meningkatkan angka kematian karena campak, serta menyebabkan keterlambatan pertumbuhan. Rata-rata konsumsi vitamin A contoh sebelum pemberian sarapan adalah $143 \mu \mathrm{g}$ RE dan sesudah pemberian sarapan menu sepinggan meningkat menjadi $363.8 \mu \mathrm{g}$ RE.

Berdasarkan hasil uji statistik menggunakan $u j i$ beda $t$, terdapat perbedaan yang signifikan antara rata-rata konsumsi vitamin $A$ contoh sebelum dan sesudah pemberian menu sepinggan $(p<0.05)$. Peningkatan asupan vitamin A tersebut sebesar $42.3 \%$. Hasil ini berbeda dengan studi Jacoby dan Pollitt (1996), yang menyatakan bahwa program sarapan sekolah di Peru belum dapat meningkatkan asupan vitamin $A$, walaupun sudah diberikan $60.0 \%$ dari kecukupan siswanya.

Distribusi contoh berdasarkan tingkat kecukupan vitamin A sebelum dan sesudah pemberian menu sepinggan terdapat pada Tabel 5. Pemberian sarapan menu sepinggan berdampak positif terhadap tingkat kecukupan vitamin A contoh. Hal ini dapat dilihat dari menurunnya jumlah contoh yang termasuk dalam kategori kurang (dari 96.8\% turun menjadi $82.3 \%$ ), dan yang termasuk kategori cukup meningkat dari $3.2 \%$ menjadi $17.7 \%$. Berdasarkan hasil uji statistik menggunakan uji beda $t$, terdapat perbedaan yang signifikan antara rata-rata tingkat kecukupan vitamin A sebelum dan sesudah pemberian sarapan menu sepinggan $(p<0.05)$. Angka kecukupan vitamin $A$ untuk anak usia 9 tahun adalah 500 ug RE/hari, anak usia 10-12 tahun adalah 600 ug RE/ hari untuk pria dan wanita (WNPG 2004). 
Tabel 5. Distribusi Tingkat Kecukupan Vitamin A dan Fe Contoh Sebelum dan Sesudah Pemberian Menu Sepinggan

\begin{tabular}{lcccccccc}
\hline \multirow{1}{*}{ Klasifikasi } & \multicolumn{4}{c}{ Sebelum } & \multicolumn{3}{c}{ Sesudah } \\
\cline { 2 - 9 } & \multicolumn{2}{c}{ TK Vit. A } & TK. Fe & \multicolumn{2}{c}{ TK Vit. A } & \multicolumn{1}{c}{ TK. Fe } \\
\cline { 2 - 9 } & 2 & 3.2 & 1 & 1.6 & 11 & 17.7 & 13 & 21.0 \\
Cukup & 60 & 96.8 & 61 & 98.4 & 51 & 82.3 & 49 & 79.0 \\
Kurang & 62 & 100.0 & 62 & 100.0 & 62 & 100.0 & 62 & 100.0 \\
Total & 62 &
\end{tabular}

\section{Konsumsi dan Tingkat Kecukupan Zat besi (Fe)}

Anemia gizi merupakan salah satu masalah gizi di Indonesia. Sebagian besar anemia gizi adalah gizi besi. Penyebab anemia gizi besi terutama karena makanan yang dimakan kurang mengandung besi, terutama dalam bentuk besi-hem. Di samping itu pada perempuan karena kehilangan darah waktu haid. Berbagai hasil penelitian menunjukkan bahwa anemia dapat menurunkan prestasi belajar. Untuk dapat mencapai prestasi maksimal, masalah anemia harus ditangani secara sungguh-sungguh. Beberapa hasil penelitian menunjukkan bahwa prevalensi anak-anak SD yang menderita anemia sekitar $40 \%$ (Muhilal 1998). Di Indonesia oleh Soemantri dan Almatsier dalam Muhilal (1998) dinyatakan bahwa terjadi peningkatan prestasi belajar pada anakanak sekolah dasar bila diberikan suplemen besi. Dari telaah berbagai makalah dan laporan penelitian di Indonesia menggambarkan, bahwa kekurangan konsumsi dibandingkan dengan kecukupan besi sekitar 50\% (Muhilal 1998). Kadar besi dalam darah meningkat selama pertumbuhan hingga remaja. Kadar besi otak yang kurang pada masa pertumbuhan tidak dapat diganti setelah dewasa. Defisiensi besi berpengaruh negatif terhadap fungsi otak, terutama terhadap fungsi sistem neurotransmitter (pengantar saraf). Akibatnya, kepekaan reseptor saraf dopamin berkurang yang dapat berakhir dengan hilangnya reseptor tersebut, sehingga menyebabkan daya konsentrasi, daya ingat, dan kemampuan belajar terganggu.

Rata-rata konsumsi zat besi ( $\mathrm{Fe}$ ) contoh sebelum pemberian sarapan adalah 5.5 gr dan sesudah pemberian sarapan menu sepinggan meningkat menjadi 10.3 gr. Berdasarkan hasil uji statistik menggunakan uji beda $t$, terdapat perbedaan yang signifikan antara rata-rata konsumsi Fe contoh sebelum dan sesudah pemberian menu sepinggan $(p<0.05)$. Peningkatan asupan Fe tersebut sebesar $30.0 \%$. Hasil ini mendukung studi Jacoby dan Pollitt (1996), yang mengemukakan bahwa program sarapan sekolah di Peru, secara signifikan meningkatkan asupan zat besi sebesar $60.0 \%$ (sarapan mengandung zat besi $100 \%$ dari kecukupan siswa).
Distribusi contoh berdasarkan tingkat kecukupan $\mathrm{Fe}$ sebelum dan sesudah pemberian menu sepinggan terdapat pada Tabel 5 . Pemberian sarapan menu sepinggan berdampak positif terhadap tingkat kecukupan Fe contoh. Hal ini dapat dilihat dari menurunnya jumlah contoh yang termasuk dalam kategori kurang (dari $98.4 \%$ turun menjadi 79.0\%), dan yang termasuk kategori cukup meningkat dari 1.6\% menjadi $21.0 \%$. Berdasarkan hasil uji statistik menggunakan uji beda $t$, terdapat perbedaan yang signifikan antara rata-rata tingkat kecukupan Fe sebelum dan sesudah pemberian sarapan menu sepinggan $(p<0.05)$. Angka kecukupan Fe untuk anak usia 9 tahun sebesar $10 \mathrm{mg}$, anak (laki-laki) usia 10-12 tahun sebesar $13 \mathrm{mg}$ dan anak (perempuan) sebesar $19 \mathrm{mg}$. Kecukupan Fe untuk usia 13 tahun (laki-laki) sebesar $19 \mathrm{mg}$ dan (perempuan) sebesar 26 mg (WNPG 2004).

\section{KESIMPULAN}

Rata-rata kandungan energi sarapan menu sepinggan contoh adalah $436 \mathrm{kkal}, 10$ gram protein, $136.6 \mu \mathrm{g}$ RE vitamin A, dan $1.97 \mathrm{mg}$ Fe dengan biaya Rp 3 000/porsi. Pemberian menu sarapan sepinggan meningkatkan konsumsi energi, protein, vitamin A dan $\mathrm{Fe}$ contoh sehingga tingkat kecukupan energi dan ketiga zat gizi tersebut (protein, vitamin A dan $\mathrm{Fe})$ juga meningkat.

\section{DAFTAR PUSTAKA}

Boushey CJ et al. 2009. Use of technology in children's dietary assessment. Eur J Clin Nutr, 63(Suppl 1), S50-S57.

Comstock EM, RG St. Pierre, \& YD Mackiernan. 1981. Measuring individual plate waste in school lunches. Visual estimation and children's ratings vs. actual weighing of plate waste. Journal of the American Dietetic Association, 79, 290-296.

Cueto \& Chinen. 2008. Educational impact of a school breakfast program in rural Peru. International Journal of Educational Development, 
Sinaga dkk.

28, $132-148$.

Jacoby \& Pollitt. 1996. Benefits of a school breakfast programme among andean children in huaraz, Peru. Food and Nutrition Bulletin, 17(1), 54-64.

Judhiastuty F. 2005. Nutrition Education : It has never been an easy case for Indonesia. Food Nutrition Bulletin, 26(2 suppl.2), S267-S274.

[Kemendagri RI]. 2010. Pedoman Umum Penyediaan Makanan Tambahan Anak Sekolah (PMTAS) melalui Pemberdayaan Masyarakat. Kemendagri, Jakarta.

Kikafunda JK \& Tumwine JK. 2006. Diet and socioeconomic factors and their association with the nutritional status of pre-school children in a low income suburb of Kampala City, Uganda. East African Medical Journal, 3(10), 565-574.

Kustiyah dkk. 2006. Pengaruh Intervensi Makanan Kudapan Terhadap Peningkatan Kadar Glukosa Darah dan Daya Ingat Anak Sekolah Dasar. Media Gizi \& Keluarga, 30(1), 42-57.

Muhilal H. 1998. Program makanan tambahan anak sekolah di negara lain dan di Indonesia. Gizi Indonesia, 23, 1-9.

Powell CA et al. 1998. Nutrition and education: A randomized trial of the effects of breakfast in rural primary school children. Am J Clin Nutr, 68, 873-9.

Salimar dkk. 2010. Laporan Analisis Lanjut Data Riskesdas 2010: Faktor-faktor yang Berhubungan dengan Status Gizi Anak Usia Sekolah (6-12 tahun) di Indonesia. Pusat Penelitian dan Pengembangan Gizi dan Makanan, Badan Penelitian dan Pengembangan Kesehatan Kementerian Kesehatan RI, Bogor.

Sinaga T. 2007. Bahan Pelatihan "Gizi Untuk Anak Sekolah". Yayasan Kuliner, Jakarta.

Soetrisno, Almasyhuri, Karyadi. 2005. Pengaruh makanan tambahan glikemik tinggi terhadap peningkatan konsentrasi belajar siswa sekolah dasar. Penelitian Gizi Makan, 28(2): 83-91.

Studdert L \& Soekirman. 1998. School feeding in Indonesia: a community based programme for child, school and community development. SCN News, 16, 15-16. 